\title{
Oespaço das múltiplas leituras na preparação de profiessores deensino religioso - o mundo dos mitos, contos e poesia
}

\section{Araceu Sobreira Beneudes \\ Doutora emEducação pela UFRN. Professora de Literatura e Religião do Curso de Ciências da Religião UERN/Campus de Natal. Pesquisadora da Fundação de Apoio à Pesquisa do Estado do Rio Grande do Norte - FAPERN.}

Resumo: Propondo a prática da leitura como uma experiência dialógica voltada para a autonomia dos leitores, este trabalho focaliza a leitura de textos literários na formação de professores de Ensino Religioso. Ao aproximar a leitura literária como fenômeno religioso, objeto de estudo das Ciências da Religião, apresentamos uma reflexão sobre práticas que possam senir como alternativa para a prática pedagógica da leitura nos espaços escolares. Pretendemos contribuir para a rediscussão de como as transformações e os ganhos didáticos podemser gerados a partir de ações significativas de leitura, construídas no espaço da formação docente.

Palavras-chave: Leitura literánia. Formação docente. Ensino religioso
Abstract: Proposing the practice of reading as a dialogic experience toward the autonomy of readers, this paper focuses on the reading of literary texts in formation of religious teachers. By bringing the literary reading with the religious phenomena, the object of study for Science of Religion, presents a reflection on practices which can serve as an altemative to the pedagogical practice of reading in school spaces. This study will contribute to the renewed the discussion of significant gains in reading practice, built in the area of teacher education.

Keymords: Literary reading. Teacher training. Religious education 

Este artigo discute a importância da leitura literária no curso de Licenciatura em Ciências da Religião/UERN - área de formação do docente do Ensino Religioso - como preparação para um conhecimento pedagógico construído na vivência do componente curricular Literatura e Religião. ${ }^{1}$ Nosso objetivo é mostrar como a leitura de textos literários pode contribuir para a formação de um repertório discursivo indispensável para os saberes da docência, compreendidos como um saber plural, provenientes da formação profissional, dos saberes das disciplinas, dos currículos e da experiência. (TARDIF; LESSARD; LAHAYE, 1991). Assim, nosso ponto de partida considera a construção dos saberes da docência como diretamente ligada às práticas de linguagem e ao contexto social, ao tempo, às condições materiais e aos aspectos sócio-histórico-culturais que fazem parte integrante do processo pedagógico da formação inicial de professores. Pelo fato de estarmos envolvida com a atividade de formação de professores-leitores com base na perspectiva dialógica da linguagem, focalizaremos a necessidade de experiências significativas com textos literários em uma abordagem inter/trans-disciplinar.

\section{Notas sobreo percurso}

As preocupações que deram origem às questões postas neste trabalho partem de nossa experiência como professora formadora em Letras e Pedagogia e que nos acompanharam para o curso de Licenciatura em Ciências da Religião da Universidade do Estado do Rio Grande do Norte, Campus de Natal, para o qual fomos transferidas no ano de 2005. De nossa prática anterior, desenvolvemos, neste curso, algumas atividades cujo foco direciona-se para a formação leitora e, no trabalho em sala de aula da disciplina Literatura e Religião, além de situarmos o contexto da constituição de leitores de textos literários, focalizamos também a relação teoria-prática que direcionará as ações pedagógicas de nossos alunos

\footnotetext{
${ }^{1}$ Este artigo discute de modo ampliado e revisto a mesma temática apresentada durante comunicação oral realizada no III Colóquio ALED Brasil. Edição 2010.
} 
tanto no momento do estágio quanto no momento em que assumirem suas salas de aula efetivamente.

Procedendo assim, atuamos com base em Kramer; Jobim e Souza (1996, p.14) que sugere uma formação concebida como "[...] o ato de educar de uma forma viva [...]", que supere "[...] as abordagens que dicotomizam trabalho e vida, tomando assim o trabalho como a vida e vice-versa”. Essa autora ainda acrescenta: “[...] é urgente agir na escola com linguagem e na linguagem, rompendo com uma concepção de linguagem como meio de, como instrumento vazio, passando a entendê-la como expressão viva de experiências vivas, do presente e do passado" (KRAMER, JOBIM E SOUZA, 1996, p.17). Desse modo, nossas ações direcionam-se para uma prática de formação que aproxime a leitura literária da vida de futuros professores, de modo a se construírem experiências significativas com os textos que circulam no mundo particular de onde se origina cada sujeito aprendente da formação docente, ao mesmo tempo em que toma conhecimento de novos textos necessários para um repertório discursivo para a prática pedagógica.

Este estudo é fruto de nossa participação como formadora docente numa Licenciatura recém-criada no campo das Ciências Humanas e é parte de reflexões teórico-metodológicas de uma pesquisa interpretativista intitulada Saberes das práticas docentes no contexto do Ensino Religioso - entrecruzando a multidisciplinaridade, leituras e experiências na construção de identidades docentes, realizada na UERN.

\section{Siturendb a formação de professores em Ensino Religioso}

$\mathrm{Na}$ última década, a criação de cursos de Licenciaturas em Ciências da Religião, no Brasil, implementou um caráter científico responsável pelo embasamento teórico (CORTELLA, 2006) necessário à formação de professores de Ensino Religioso das escolas públicas e privadas do país. Essa preocupação 
com a formação inicial aconteceu após o entendimento da necessidade de uma formação específica para os educadores/as envolvidos com a prática dessa disciplina, compreendida, atualmente, de modo não proselitista, afastando-se do modelo moralizante e catequista do ensino de religião, comumente encontrado em décadas atrás em nosso contexto educacional.

O atual modelo propõe ações mais abertas, menos preconceituosas e mais diversificadas no tratamento da heterogeneidade religiosa presente nas escolas. Dessa forma, o foco dessa disciplina direciona-se para a diversidade e para o pluralismo religiosos reconhecidos como marcas da cultura brasileira.

No entanto, mesmo com essas mudanças e a elaboração dos Parâmetros Curriculares Nacionais do Ensino Religioso (FONAPER, 1997), os conteúdos voltados à prática pedagógica ainda estão em fase de construção em muitos cursos de formação docente na área. Além disso, a dificuldade de se trabalhar com a diversidade religiosa esbarra na ausência de uma compreensão mais recente, na prática de professores, que não tiveram nenhum tipo de formação específica nesse campo de conhecimento e que a lecionam do mesmo modo que antigamente, ou seja, com base nas orientações de uma religião exclusiva [quase sempre a católica] e de modo dogmático. Essa é uma realidade presente em muitas escolas da região metropolitana de Natal/RN e, com base nisso, iniciamos, desde 2008, um trabalho investigativo (BENEVIDES, 2011a; 2011b) que pretende colaborar na compreensão daquilo que acontece no contexto escolar, ao se analisar a que saberes os docentes dessa área de conhecimento recorrem para a transposição didática do Ensino Religioso. Os resultados desse trabalho começam a encaminhar ações voltadas para a formação inicial de professores dessa disciplina com base na construçẫo de um repertório para as práticas pedagógicas futuras.

Como ponto de partida para nossa discussão, referimo-nos a um dado retirado da investigação 
mencionada acima, cujo foco é a interpretação dos discursos que revelam a constituição das identidades e dos saberes de docentes de Ensino Religioso em escolas públicas da região metropolitana de $\mathrm{Natal} / \mathrm{RN}$ e que não possuem formação específica. Pelo fato de até 1997 não haver a obrigatoriedade de formação em nível superior para esses profissionais, muitos atuavam com base em uma formação religiosa ou com base em uma formação acadêmica na área pedagógica. Para esses professores, estava pressuposto que, para o ensino da Religião (nome dado à disciplina em períodos passados da história da educação brasileira), não era necessária formação específica, bastava-se possuir fé e ser catequizador ou evangelizador para estar em sala de aula.

Assim, ao analisarmos as respostas dadas pelos sujeitos participantes da pesquisa - professores da rede estadual de ensino - ao questionário investigativo que indagava a qual tipo de material o docente recorria quando preparava a aula de Ensino Religioso, uma das respostas recorrentes indicou que o planejamento do conteúdo tomava o "estudo da Bíblia" como orientação para as leituras realizadas em sala de aula. Um dado também exposto no corpus desse estudo indica a pesquisa à internet e/ou a obras de cunho religioso cristão como suporte para a organização das aulas. (BENEVIDES 2011a).

O contexto da formação específica na área das Ciências da Religião, por outro lado, oportuniza a interação com conhecimentos didático-metodológicos que organizam/sistematizam procedimentos que não estão presentes em práticas baseadas apenas "no estudo da Bíblia”. As ações docentes construídas nesse espaço transformam-se em formatos típicos de situações escolares, deixando de possuir a característica de aula de catecismo, como ocorria em décadas anteriores. Nesse sentido, defendemos que as aulas de Ensino Religioso precisam de planejamento, com base em conteúdos selecionados em critérios educativos e não apenas 
voltados para os dogmas ou conhecimentos de uma religião específica. Nesse entendimento, a formação poderá indicar para os docentes modos diferentes de “[...] explicar conceitos complexos, coordenar discussões, avaliar a aprendizagem do aluno, controlar a sala de aula, e assim por diante [...]". (ZEICHNER, 2003, p. 47), mesmo que esses conceitos complexos tenham como tema as questôes do Transcendente ou do fenômeno religioso - entendido como o objeto de estudo das Ciências da Religião e foco para o qual recai a organizaçẫo curricular da disciplina Ensino Religioso. Nesse caso, as atuais orientações encaminham-se para um ensino pluralista, o qual concebe a existência de textos sagrados de matrizes religiosas variadas conforme os tipos de sociedades e os tempos históricos aos quais pertencem. $\mathrm{O}$ acesso a esses textos pauta-se na compreensão de que não há verdades únicas, característica diversa daquela adotada pelo ensino dogmático.

A leitura que leva em consideração apenas o "estudo da Bíblia" retira a possibilidade de o/a aluno/a de escolas públicas ${ }^{2}$ ter contato com outros textos de escrituras sagradas que não sejam as do mundo cristão. Dessa forma, não somente a Bíblia possui espaço para a compreensão das narrativas sagradas que a formam, mas narrativas como as que estão nos livros sagrados do Islamismo, do Budismo, do Hinduísmo, entre outras concepções religiosas (BIERLIEN, 2003), precisam adentrar as salas de aula, com suas visões de mundo, experiências e valores. Para exemplificar, trazemos pequenos enunciados de narrativas que explicam o mito da Criação por outras perspectivas culturais que não aquela existente no livro Genesis, da Bíblia judaico-cristã:

Enunciado 1

Depois de algum tempo na terra, Nü Gua sentiuse solitária e percebeu que ainda faltava algo no mundo. Certo dia, ela viu seu reflexo em um lago e teve uma ideia. Pegou um punhado de lama e moldou-o como uma cópia diminuta de si
${ }^{2} \mathrm{O}$ Ensino Religioso é matéria prevista do quadro de disciplinas do Ensino Fundamental público. 
mesma: o primeiro humano. Quando a deusa pôs a criatura no chão, esta imediatamente ganhou a vida e começou a gritar e a dançar de alegria. Satisfeita com sua obra, Nü Gua pegou mais lama e fez uma grande quantidade de pessoas. Elas saíram vagando pela região, mas ela sempre podia ouvir suas vozes e nunca mais se sentiu sozinha [...]. (WILLIS, 2007, p. 91).

Enunciado 2

A mulher e o homem sonhavam que Deus os estava sonhando.

Deus os sonhava enquanto cantava e agitava suas maracas, envolvido em fumaça de tabaco, e se sentia feliz e também estremecido pela dúvida e o mistério.

Os índios makiritare sabem que se Deus sonha com comida, frutifica e dá de comer. Se Deus sonha com a vida, nasce e dá de nascer. A mulher e o homem sonhavam que no sonho de Deus aparecia um grande ovo brilhante. Dentro do ovo, eles cantavam e dançavam e faziam um grande alvoroço, porque estavam loucos de vontade de nascer. Sonhavam que no sonho de Deus a alegria era mais forte que a dúvida e o mistério; e Deus, sonhando, os criava, e cantando dizia: - Quebro este ovo e nasce a mulher e nasce o homem. E juntos viverão e morrerão. Mas nascerão novamente. Nascerão e tornarão a morrer e outra vez nascerão. E nunca deixarão de nascer, porque a morte é mentira (GALEANO, 2010, p.25).

Os exemplos acima tornam-se material pedagógico para aulas de Ensino Religioso numa perspectiva de construção de pontos de vista variados sobre o que se conhece globalmente como Mito da Criação. O professor que atua nessa compreensão amplia os horizontes de seus estudantes ao contrapor o discurso da verdade única existente, muitas vezes, no modelo catequista que dominou no sistema educacional brasileiro desde o período colonial até o período mais recente, quando se iniciou o processo de mudança da disciplina. 
Assim, no conjunto das leituras desenvolvidas na disciplina Literatura e Religião, destacamos alguns textos que contam a origem da criação (do mundo e do homem) a partir de diferentes concepções religiosas. Também compartilhamos narrativas literárias que estabelecem diálogo com o discurso religioso ou que são releituras de textos sagrados. Por exemplo: Os contos Vicente, de Miguel Torga, e Na Arca - Três capítulos inéditos do Gênesis, de Machado de Assis, são releituras da narrativa contada em Gênesis, texto da concepção judaico-cristã. ${ }^{3}$ É partindo dessa compreensão que propomos levar para a formação de professores de Ensino Religioso o envolvimento com o mundo literário para a construção de uma prática reflexiva e coerente, articulada ao mundo que pode ser descoberto pelos estudantes, principalmente aqueles de escola pública. Isso não quer dizer que essa tarefa seja facilmente incorporada no mundo da prática docente. Relacionar modos de se entender outros pontos de vista, principalmente em se tratando de religião, é uma atividade que exige preparação, porque pressupõe não apenas respeito e tolerância para as diferenças alheias, mas a compreensão do diferente e da descoberta de que a versão para uma narrativa sagrada, por exemplo, pode ter possibilidades várias de registro e de construção de valores, como é o caso dos contos que narram o Dilúvio em diferentes grupos sociais e mesmo por autores consagrados, como Machado de Assis e Miguel Torga.

Outro aspecto para o qual chamamos atenção em relação à necessidade de formação específica em Ciências da Religião para que se possa atuar efetivamente em salas de aula de Ensino Religioso é o que aparece nas entrelinhas do que é dito quando se afirma que "no estudo da Bíblia" encontram-se os fundamentos para a preparação de uma aula. Essa compreensão denota nitidamente que se pode selecionar qualquer assunto para ser abordado em sala de aula e que o conhecimento da disciplina pode ser organizado a partir de escolhas subjetivas e que não incorporam modos de fazer organizados, procedimentos
${ }^{3} 0$ acesso a estes

contos pode ser feito via internet. Alguns caminhos: <http:// boticelli.no.sapo.pt/ miguel_torga.htm>; < http://pt.wikisource.org/ wiki/Na_arca>. 
específicos e atividades e decisões compartilhadas em um contexto definido: a sala de aula.

Pode-se pensar que pelo simples fato de alguém possuir uma fé, conhecer determinado texto sagrado que envolve essa fé, está capacitado para lecionar sobre isso.

Entendemos que a formação acontece de modo processual e contínuo e nunca fruto do improviso. Ao contrário, pelo fato de possuir um caráter organizado é que sentimos a necessidade de compreender as ações que se desenrolam no espaço da formação inicial, neste caso, a Licenciatura em Ciências da Religião, por entendermos que essa etapa é a "[...] primeira fase de um longo e diferenciado processo de desenvolvimento profissional" (GARCIA, 1999, p.27).

Com o objetivo de renovar as metodologias adotadas no contexto da prática docente existente nessa área de ensino, iniciamos uma abordagem formativa com base na proposta dialógica da linguagem (BAKHTIN, 2003), entendendo-a como atividade e ação no mundo social onde se produzem e circulam os enunciados que são envolvidos sempre por uma dimensão de pluralidade. Nesse sentido, vivemos o duplo desafio provocado por nossas experiências formadoras: instaurar uma cultura de práticas leitoras e construir uma experiência formadora orientada para a produção de conhecimentos e não para a reprodução/transmissão de conteúdos.

Nesse sentindo, voltamo-nos para a compreensão doselementos culturais presentes no mundoexperienciado pelos estudantes da formação docente, para que estes entendam o modo como a cultura escrita constitui-se na vivência de seus futuros alunos, conforme será exposto no próximo item deste trabalho.

\section{Aexperiência coma leitura litterária na Formeção dedbcentes do Ensino Religioso}

No âmbito das Ciências Humanas e Sociais alguns trabalhos vêm se destacando no sentido de debater 
o modo como as práticas leitoras são construídas na formação de professores (KRAMER, 2001; KRAMER, JOBIM E SOUZA, 1996; BATISTA, 1998; BENEVIDES, 2005). Nesses trabalhos, a preocupação maior diz respeito à forma como a leitura é assumida enquanto uma prática social, situada historicamente. Entretanto, no espaço escolar, existem contradições tão díspares que colocam essa prática de maneira quase que inexistente ou em uma posição que só existe dentro desse espaço: a da leitura/ escrita didatizada. Dessa forma, tais estudos informam sobre a importância de se construir uma compreensão sobre as práticas leitoras a partir das experiências pessoais investigadas nas trajetórias de professores.

Com base nesses estudos, iniciamos nossa atuação no curso de Ciências da Religião, trabalhando com um referencial teórico que ampliasse a compreensão da dimensão pessoal com a leitura literária para a construção de práticas norteadoras para as ações docentes. A adoção de uma postura reflexiva sobre os modos como os sujeitos constroem suas relações com o mundo da escrita articulou uma ação pedagógica voltada para a discussão sobre o papel da escrita no mundo da vida através dos textos que circulam no cotidiano (KRAMER, JOBIM E SOUZA, 1996).

$\mathrm{Na}$ sondagem com os estudantes, avaliamos a fragilidade das experiências pessoais com a vivência da leitura literária, como podemos ver no trecho retirado de um relato pessoal produzido por um de nossos alunos, no contexto acadêmico, em 2008, e que servirá de corpus para nossos posicionamentos neste artigo:

Para começar a minha história de leitura devo primeiro relatar aqui a minha história de nãoleitura. Um período da minha vida onde, apesar de estar repleto de atividades de letramento e leitura, eu não lia e tudo que fazia era reproduzir sem muita reflexão ou composição logica-textual. $\mathrm{O}$ fato de estar sempre estudando e nunca ter repetido de ano na escola regular não significava

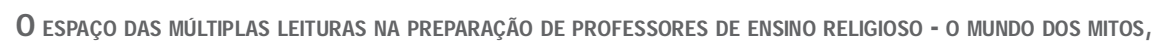




\footnotetext{
${ }^{4}$ Este relato foi compilado tal qual produzido pelo estudante. Não fazemos qualquer referência que identifique o autor do texto que, apesar de ter participado voluntariamente da proposta do projeto ao qual este estudo se prende, tem garantido que o uso que se faz do conteúdo de seu relato está em conformidade às exigências do Comitê de Ética da UERN, parecer $n^{0}$ 098/2010.
}

muito para minha vida de leitor, ou melhor "nãoleitor". [...] E assim vamos aprendendo ano após ano que ler é importante, que quem lê é uma pessoa instruída, mas instruída pra que? [sic] Ler é importante por quê? Ler o que? [sic] Como? Que leitores nos formamos da maneira que aprendemos a ler? Na academia, na universidade, por exemplo. Quando entrei lá estava com uma estranha vontade de ler, ler pra ter "cultura", ler pra saber um pouco mais sobre o que não se sabe. No começo então, nos primeiros períodos, eu queria ler todos os livros que os professores indicavam, porém aos poucos fui percebendo que não seria possível. Então fui frustrado pelo tempo, não dava pra ler tudo aquilo e a maioria era interessante. Como ficava então? Eu tinha que ler de alguma forma. Dei um jeito de ler o mais rápido possível pra ler o máximo de textos possível. O meu problema parecia estar se resolvendo, mas o que eu estava lendo? Já não sabia mais. Eram tantas informações, tantos textos diferentes, tantas temáticas nada simples sendo abordadas todas ao mesmo tempo. (Relato produzido por um aluno do Curso de Ciências da Religião, 2008). ${ }^{4}$

Pelo teor das palavras contidas no relato, interpretamos que a experiência vivida por esse estudante não é característica apenas de alunos do curso de Ciências da Religião, mas pertence à realidade de outros estudantes de cursos das Ciências Humanas. Outro complicador que gerou debates em sala de aula consiste no fato de que esses estudantes que nos informam essa situação desconhecem autores e obras da literatura cuja temática gira em torno do discurso religioso e que não sejam aqueles mais famosos que "caem no Vestibular", como Machado de Assis, sobre quem o estudante escolhido entre aqueles que participaram de nossa sondagem, naquele semestre, comenta:

Por que ninguém me disse que Machado de Assis falava da mente das pessoas? Tivessem me dito isso eu o teria lido mais cedo no ensino fundamental 
e gostaria da leitura, mas provavelmente meus professores daquele período o julgaram muito difícil pra mim. [...]

Escolhemos esse relato dentre os demais pela força das palavras do autor, isto é, o significado de uma vivência marcada por conflitos, rupturas, muito mais ausência do que presença e que, no ambiente da formação de professores, possui um peso a mais para as reflexões sobre como tornar a prática leitora uma ação na vida dos aprendizes, seja no contexto acadêmico seja no contexto da escola de ensino básico. Esse relato representa uma imagem bem conhecida da vida daqueles que estão em cursos de Licenciaturas, e seu teor resume a experiência com as dificuldades que existem quando o trabalho de formação/constituição de leitores é feito de modo alheio ao que a vida acadêmica exige de fato. Embora o estudante diga-nos um pouco sobre como a leitura esteve em sua passagem pela escola, encontramos indícios de que pouco conhece também da relação estreita entre literatura e religião, principalmente no que tange à origem da leitura - como uma prática de compreensão de significados - e à origem da leitura de textos literários, realizada pelos sumérios há cerca de 2.500 anos (a.C).

Ao mergulhar na compreensão de que a leitura, a literatura e a religião estão intimamente ligadas em suas origens (FISCHER, 2006), os estudantes da formação iniciaram um longo processo de imersão em textos literários, isso porque entendemos que os professores precisam se assumir como sujeitos leitores para poder enfrentar o desafio de "[...] ensinar a ler e a gostar de ler". (SILVA; ZILBERMAN, 1988, p. 111).

Trazendo para discussão as palavras do aluno quando relembra "O fato de estar sempre estudando e nunca ter repetido de ano na escola regular não significava muito para minha vida de leitor, ou melhor "não-leitor", podemos reconhecer que nem sempre tudo que parece tão organizado enquanto representação de um modelo

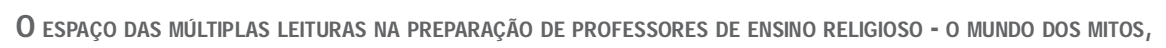


de vivência escolar indica a transparência daquilo que acontece no interior de uma sala de aula. Um dos efeitos dessa reflexão atinge diretamente as ações pedagógicas na fase da formação inicial de professores, porque pensamos que, quando esses futuros profissionais conseguem visualizar como a prática da leitura esteve em sua própria vida, podem compreender e transformar suas futuras ações em relação às

[...] interações e contraditórias de suas histórias, fragmentos, ruínas, estilhaços da vida contemporânea, que revelam o que o chamado "mundo moderno" tem feito de suas (e nossas) histórias, e como a escola tem contribuído para essa fragmentação, desprazer, didatização do real. (KRAMER, JOBIM E SOUZA, 1996, p.40).

Essas contradições ficam destacadas nas palavras de nosso informante: "[...] E assim vamos aprendendo ano após ano que ler é importante, que quem lê é uma pessoa instruída, mas instruída pra que?[sic] Ler é importante por quê? Ler o que? [sic] Como? Que leitores nos formamos da maneira que aprendemos a ler ?”.

Relacionando essa temática com as situações vivenciadas pela/na prática social da leitura, podemos dizer que isso também acontece com o ato de ler, que não pode ser dissociado do mundo da vida, do contexto onde a sua significação depende da situação imediata para que se estabeleça o diálogo entre os membros (interlocutores) envolvidos nesse ato: autor, leitor, enunciados e os juízos de valor (posicionamentos) presentes nos enunciados. Em síntese: os sistemas simbólicos, que estão presentes no domínio da cultura, não podem ser compreendidos separadamente do mundo da vida (BAKHTIN, 2003).

Os conflitos que surgem na busca dessa compreensão são, muitas vezes, justificados, porque, primeiramente, são sentidos que se querem construir abstratamente; em segundo lugar, são sentidos que se buscam em realidades distintas das dos sujeitos envolvidos 
na situação de aprendizagem, por exemplo, quando os/ as alunos/as estão desinteressados pelos conteúdos por estes serem totalmente alheios à realidade vivenciada por aqueles ou pela total falta de tempo, como ainda revela o aluno que conosco compartilha suas vivências: "Então fui frustrado pelo tempo, não dava pra ler tudo aquilo e a maioria era interessante. Como ficava então? Eu tinha que ler de alguma forma. Dei um jeito de ler o mais rápido possível pra ler o máximo de textos possível"; e, por último, quando se querem construir sentidos únicos, considerados como verdadeiros, impostos, sem a percepção, por parte dos interlocutores, de suas posições axiológicas trabalhadas em relação às posições axiológicas contidas nos enunciados. Esses aspectos contribuem para que os modos de ler sejam limitados, tendo como impacto a inexistência de apropriação de um mundo escrito com o qual nosso aluno acima gostaria de ter dialogado.

Desse modo, assumimos a prática dialógica da leitura como sendo aquela que envolve não apenas a interação dos sujeitos circunscritos ao ato de ler: autor/leitor (estudantes e professores-formadores) e os enunciados (escritos ou falados), mas também as relações axiológicas trazidas pelos valores presentes nesses enunciados, a percepção dos jáditos, pela qual se antecipam as vozes do outro, suscitando o ainda por dizer (devir).

Nessa concepção, a compreensão da palavra do outro exige duas consciências, dois sujeitos que interagem, na relação de sentido que nela se constrói. Isso porque não existem "[...] palavras sem voz, palavras de ninguém" (BAKHTIN, 2003, p.330). Essa relação é de ordem mais complexa, mais ampla e diversificada. A compreensão não pressupõe aqui apenas a aceitação ou a concordância com o que se diz ou lê, pressupõe o conflito, a discordância, a repetição e a transformação. Mesmo que nessa compreensão apresentem-se também as dificuldades e as tentativas de se superar o que não é tão fácil, como podemos ver nas palavras do estudante do Curso de Ciências da Religião, quando este polemiza 
sobre sua condição de leitor: "O meu problema parecia estarse resolvendo, maso que eu estava lendo? Já não sabia mais. Eram tantas informações, tantos textos diferentes, tantas temáticas nada simples sendo abordadas todas ao mesmo tempo".

Com base nisso, vislumbramos a complexidade que é instaurar uma prática leitora no ambiente acadêmico, pressupondo a ausência de uma leitura como parte da rotina das práticas de letramento que antecedem o período em que se ingressa em um curso universitário.

É nesse sentido que o trabalho com textos literários, como, por exemplo, com o poema A filha da antiga lei, de Adélia Prado, responde a esse processo dialógico que se estabelece diante do leitor que se confronta diante do pensamento religioso contido nos questionamentos provocados pela autora:

Deus não me dá sossego.

É meu aguilhão.

Morde meu calcanhar como serpente, faz-se verbo, carne, caco de vidro, pedra contra a qual sangra a minha cabeça. Eu não tenho descanso neste amor.

Eu não posso dormir sob a luz do Seu olho que me fixa.

Quero de novo o ventre de minha mãe, sua mão espalmada contra o umbigo estufado, me escondendo de Deus.

(PRADO, 1991)

O poema de Adélia Prado convoca o leitor a percepções várias no plano do sagrado e do profano, aspectos presentes nos Parâmetros Curriculares do Ensino Religioso e que precisam compor os saberes de docentes dessa disciplina. A construção poética de Prado colabora para o desmonte das leituras rígidas e monológicas presentes de várias formas no discurso dogmático, enriquecendo as compreensões dos leitores pela provocação ao estabelecido. 
O conhecido e o desconhecido adentram no plano da poesia, pela seleção de autores de renomes que tratam das questões transcendentais e que, infelizmente, não fazem parte de uma leitura cotidiana nem da vida dos estudantes nem da vida de professores, conforme vemos em Benevides (2005). O trabalho com esse tipo de poesia objetiva ainda a introdução de atividades orais com foco para apresentações públicas (declamação, rodas de poesia) no sentido de se dar ênfase aos componentes expressivos da linguagem poética posta em movimento pelo sentido dado ao trabalho em grupo, focalizando apresentações e situações comunicativas em que os textos tivessem uma audiência explícita, ou seja, que a vivência com a poesia não ficasse unicamente em uma leitura silenciosa e descarnada da vida. Nesse sentido, apoiamo-nos em Tezza (2006, p. 252), quando este discute a autoridade poética:

O poeta funda sua autoridade em duas pontas: na audiência concreta e social que crê, aceita e outorga ao poeta o seu direito de dizer, e no imaginário do seu tempo que reserva a quem escreve um quadro de valores dentro do qual a literatura, ou a poesia, fará sentido.

Outro exemplo a destacar em relação à construção de práticas leitoras relaciona o mundo do fenômeno religioso e as temáticas deste, frequentemente presentes em contos da cultura popular brasileira.

Nesse campo do fazer, proporcionamos a aproximação dos estudantes ao mundo de Câmara Cascudo (2004) e Azevedo (2005a, 2005b). Ainda relacionamos ao ato de ler, à atividade de contação oral (BUZZATO, 2003), pouco trabalhada em outros momentos da vida desses alunos. No decorrer da disciplina, alguns estudantes começaram a pesquisar com familiares exemplos de contos cuja temática maior era assombração e morte. O trabalho de se analisarem os textos e suas recriações dentro da cultura popular nordestina, principalmente, representou uma etapa de 
apropriação não somente das estruturas composicionais dos enunciados como também das posições axiológicas que são assumidas no universo literário.

Esse tipo de narrativa contribui para a aproximação entre aquilo que está presente no mundo da vida e o mundo da cultura popular: a temática da morte. Azevedo se utiliza de uma linguagem popular para construir a narrativa em que a morte toma vida e vem buscar mortos pessoalmente. $\mathrm{O}$ autor cativa o leitor com o modo como trata com bom humor a questão da morte - tema nem sempre comum em salas de aula.

Nossa proposta metodológica optou por se viverem a prosa e a poesia no sentido de se recuperarem na/pela memória atos que já foram ou podem fazer parte da vida dos estudantes: contação de narrativas, como aquela(s) que acontecia(m) em comunidades rurais,

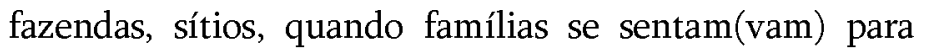
contar causos, muitas vezes histórias regadas a sustos, assombrações, personagens verdadeiramente valentes que encaram a morte. No levantamento dessas narrativas entre familiares e amigos, os estudantes da Licenciatura coletaram histórias muito parecidas com aquelas que escolhemos para leitura, com base em obras existentes como as de Cascudo (2004) e Azevedo (2005a,b), de cuja obra retiramos uma pequena passagem como amostra do tipo de compreensão da cultura popular religiosa que está muito presente no sertão brasileiro.

Certa noite, bateram na sua porta. Era um homem estranho, de cara feia, chapéu e paletó escuro.

- Zé, se prepare - disse o homem. - Sua hora chegou.

- Quem é você? - quis saber Zé Malandro.

- Sou o Diabo - respondeu o outro, tirando o chapéu e mostrando dois tristes chifres. - A Morte não quis vir de jeito nenhum, mas me mandou no lugar dela para buscar você.

- Mas como! - disse o Zé espantado. - Já? Deve haver algum engano! O Diabo caiu na gargalhada. 
- Não venha com essa conversa mole. Já estou avisado sobre você. Vamos embora agorinha mesmo. Ou vai me pedir pra subir na figueira? Nessa eu não caio! (AZEVEDO, 2005a, p. 51).

Trazer a discussão sobre a leitura literária para o ambiente acadêmico requer uma concepção clara de que uma aula de contação de histórias ou de leitura de contos ou poesia não é algo solto e aleatório no fazer da preparação docente. Assim, de acordo com Cosson, "O efeito de proximidade que o texto literário traz é produto de sua inserção profunda em uma sociedade, é resultado do diálogo que ele nos permite manter com o mundo e com os outros" (COSSON, 2006, p.29). Desse modo, a leitura literária torna-se experiência formadora, realizase como reflexo da compreensão e da relação dialógica que promove o interesse pela prática da leitura de textos desse teor (BRAIT, 2010).

\section{Oencontrar-se e o encantar-se}

Nossa proposta como educadora é fazer com que os estudantes se encontrem no curso de formação de professores e se encantem pelo fazer docente e pela palavra literária. Entretanto, acreditamos na existência de uma barreira que assusta os estudantes recém egressos do Vestibular e que se perpetua na Licenciatura: práticas de leituras nem sempre são suficientes para que eles deem conta de tudo que a graduação lhes exige.

No espaço entre uma disciplina e outra as leituras vão se acumulando e a experiência mostra-nos que é preciso muito mais do que força de vontade para fazer com que esses/as estudantes se envolvam com a responsabilidade de sua aprendizagem.

Há ainda outro aspecto que merece destaque. Ao situarmos a atividade da leitura como atividade situada na esfera do discurso (BAKHTIN, 2003), pretendemos dizer que ela pode ser construída na formação docente como manifestação da compreensão das diversas vozes 
que ressoam através do que se leu em um curso de formação. Compreensão das vozes dos autores lidos, sejam eles selecionados por representar o cânone, sejam eles selecionados por representar uma tendência ou uma preferência por parte dos/as professores/as-formadores/ as que optaram e decidiram por esta ou aquela obra. Nesse sentido, defendemos uma postura que traz aos professores-formadores/as o senso de responsabilidade ética e estética sobre o seu fazer pedagógico e sobre as escolhas que assumem ao proceder deste ou daquele modo. Nessa linha de pensamento, reportamo-nos a Bakhtin (2003) que diz que o dever, no mundo da vida, é relacionado à responsabilidade. Por isso, entendemos que a responsabilidade do/a professor/a que doa, que oferece a leitura, passa pela experiência do/a aluno/aouvinte, como orienta também Larrosa (2003), ao refletir sobre o papel formador da leitura. Disso, interpretamos que a responsabilidade do/a professor/a passa pela compreensão dos/as alunos/as, enquanto co-enunciadores do/no processo de ensino, e dos conhecimentos, enquanto produtos da cultura.

A responsabilidade/respondibilidade do/a professor/a passa, assim, pela alteridade, através das respostas ao outro, alunos/as-ouvintes, através daquilo que escolhe (elege) para oferecer a eles/as como leituras. Partimos, desse modo, do pressuposto de que, ao compreender as atividades centradas nesse cotidiano e os vários modos (gestos) de leitura que o mundo social construiu, os graduandos/as possam partir dos conhecimentos que orientam a estruturação dessas práticas para não apenas compreender a realidade escolar, mas saber o que precisam para construir práticas outras, baseados/as em sua visão de mundo e no conhecimento formalizado sobre os saberes docentes necessários para agir como professores.

Desde nossa chegada ao Curso de Ciências da Religião, trabalhamos com um leque de propostas de leitura, voltadas para o desenvolvimento da leitura 
literária, fonte para as pesquisas e planejamento indicados para a atuação docente, e tínhamos a vivência sobre como esses eventos de letramento poderiam melhorar/transformar a realidade escolar de crianças que frequentam escolas da região metropolitana de Natal. ${ }^{5}$ Esse material pode auxiliar no desenvolvimento das atividades pedagógicas do/a professor/a de ensino religioso, mas também de professores/as de língua materna e de outras disciplinas.

O material indicado para a disciplina de Ensino Religioso teve como objetivo trazer para a sala de aula uma das formas históricas existentes para a manutenção e perpetuação do fenômeno religioso nas sociedades: a leitura. De acordo com Fischer (2006, p.37):

Ao longo da história, a religião foi um dos primeiros motores da alfabetização. Os escribaspadres figurariam entre os primeiros leitores da sociedade. Depois deles, vieram os eruditos da elite e, a seguir, os celebrantes seculares que, por sua vez, expandiram e diversificaram o material de leitura, acabando por indicar um conceito de educação geral.

Em um espaço repleto de vozes religiosas como é o do discurso pedagógico do Ensino Religioso, nada mais valioso do que apresentar aos futuros professores textos literários em que essa dimensão atravessa as diversidades dos mundos, auxiliando na compreensão dos tempos e espaços discursivos que se apresentam nas diversas vozes que se constroem nos gêneros prosaicos e poéticos. Além disso, a análise de como essas vozes refratam/refletem os diversos mundos, como se confrontam, entrechocamse, discordam, afastam-se ou aproximam-se, polemizam, entrecruzam-se, completam-se e respondem umas às outras nos discursos literários - e que também estão presentes no plano da vida - aproxima os sujeitos-leitores de uma compreensão mais dialógica da palavra.
${ }^{5}$ Região onde os estágios do Curso de Ciências da Religião são realizados. 


\section{Conduindo..}

Neste trabalho, discutimos a necessidade de formação específica para a atuação de professores de Ensino Religioso, pensando nos saberes que formam os conhecimentos da prática desse profissional, principalmente depois que as mudanças mais recentes transformaram o ensino de Religião, antes dogmático e catequista, em Ensino Religioso, pluralista e não proselitista, exigindo dos professores dessa disciplina conhecimentos didáticos e epistemológicos que apresentam o fenômeno religioso como objeto de estudo.

Para a composição de parte dos saberes docentes, analisamos como a experiência leitora acontece na vida de um estudante de um Curso de Ciências da Religião, para quem essa experiência mantém-se distante das práticas cotidianas até a sua entrada no curso de Licenciatura. Intentamos apresentar alguns caminhos com a introdução de uma prática de leitura literária que leve em conta o discurso religioso. Assim, a experiência da formação de leitores não pode estar desvinculada do mundo da vida, esse é o mundo, segundo Bakhtin (1997), que não pode ser destacado da Arte e da Ciência (conhecimento). Para esse autor, o mundo autônomo, abstratamente teórico, é um mundo fundamentalmente e essencialmente alheio à historicidade única e viva. Essa concepção implica um grande impacto para os atores da educação: direciona para a sala de aula, o mundo vivo que exige do ser, aqui o sujeito envolvido no processo educativo - professores e alunos - um envolvimento, um compromisso, um ato real, vivido, não deslocado. Assim, as práticas de letramento variam de contexto para contexto, o que significa dizer que nós podemos enxergar diferentes papéis, relações, valores, mudanças, acessos e processos no interior dessas práticas. 


\section{Referências}

AZEVEDO, Ricardo. Contos de enganar a morte. São Paulo: Ática, 2005a.

. Contos e Alumbramentos. São Paulo: Scipione, 2005b.

. Conto popular, literatura e formação de leitores.

Disponível em <www.ricardoazevedo.com.br>. Acesso em 25 abr. 2010.

BAKHTIN, Mikhail. Estética da Criação Verbal. Tradução Paulo Bezerra. 4. ed. São Paulo: Martins Fontes, 2003.

. Hacia uma filosofia del acto ético. Barcelona:

Anthropos, 1997.

BATISTA, Antonio A.G. Os professores são "não-leitores"? In: MARINHO, Marildes; SILVA, Ceris Salete Ribas da. Leituras do Professor. Campinas, SP: Mercado de Letras: Associação de Leitura do Brasil - ALB, 1998, p. 23-60. (Coleção Leituras no Brasil)

BENEVIDES, Araceli Sobreira. Saberes da prática docente do Ensino Religioso. Referências para a Formação sobre a construção/constituição da identidade do/a professor/a de ER. Relatório Final de Projeto de Pesquisa. Natal: Departamento de Ciências da Religião, UERN, 2011a.

Professor religioso ou professor de Ensino Religioso - perspectivas para a formação docente. In: ANDRADE, Francisco Ari de; SANTOS, Jean Mac Cole Tavares (Org.). Formação de Professores e Pesquisas em Educação: teorias, metodologias, práticas e experiências docentes. Fortaleza: Edições UFC, 2011b, p. 32-53. 
Leitura e formação docente: a trajetória da prática

da leitura de alunos/as do curso de Letras. Natal, 2005. 313 p.

Tese (Doutorado em Educação). Programa de Pós-Graduação em Educação do Centro de Ciências Sociais Aplicadas, Universidade Federal do Rio Grande do Norte, Natal.

BIERLIEN, J.F. Mitos Paralelos. São Paulo: Ediouro, 2003.

BRAIT, Beth. Literatura e outras linguagens. São Paulo: Contexto, 2010.

BUZZATO, Cléo. Contar e Encantar- pequenos segredos da narrativa. Petrópolis (RJ): Vozes, 2003.

CASCUDO, Luiz Câmara. Contos Tradicionais do Brasil. 13. ed. São Paulo: Global, 2004.

CORTELLA, Mario Sergio. Educação, Ensino Religioso e formação docente. In: SENA, Luzia (org.). Ensino religioso e formação docente. Ciências da Religião e Ensino Religioso em diálogo. São Paulo: Paulinas, 2006, p. 11-20.

COSSON, Rildo. Letramento Literário: teoria e prática. São Paulo: Contexto, 2006.

FÓRUM NACIONAL PERMANENTE DO ENSINO RELIGIOSO - FONAPER. Parâmetros Curriculares Nacionais. Ensino Religioso. 2. ed. São Paulo: AM Edições, 1997.

FISCHER, Steven Roger. História da Leitura. São Paulo: Editora Unesp, 2006.

GALEANO, Eduardo. Os nascimentos. Memória do Fogo. Vol. 1. Porto Alegre: L\&PM Pocket, 2010.

GARCÍA, Carlos Marcelo. Formaçâo de Professores - para uma mudança educativa. Porto: Porto Editora, 1999. 
KRAMER, Sônia. Leitura e escrita como experiência - notas sobre seu papel na formação. In: ZACCUR, Edwiges (org.). A magia da linguagem. Rio de Janeiro: DP\&A: SEPE, 2001, p.101-121.

KRAMER, Sônia; JOBIM E SOUZA, Solange. Histórias de professores. São Paulo: Ática, 1996.

LAROSSA, Jorge. Sobre a lição ou do ensinar e do aprender na amizade e na liberdade. In: Pedagogia Profana. danças, piruetas e mascaradas. Tradução de Alfredo VeigaNeto. 4.ed. Belo Horizonte: Autêntica, 2003, p.139-146.

MACHADO, Irene. Os gêneros e o corpo do acabamento estético. In: BRAIT, Beth (Org.) Bakhtin, dialogismo e construção do sentido. Campinas (SP): Editora da Unicamp, 1997.

PRADO, Adélia. Poesia reunida. São Paulo: Arx, 1991.

SILVA, Ezequiel Theodoro da; ZILBERMAN, Regina.

Pedagogia da leitura: movimento e história. In: ZILBERMAN, Regina; SILVA, Ezequiel Theodoro da (org.). Leitura. perspectivas interdisciplinares. São Paulo: Ática, 1988, p.111115. (Série fundamentos, 42).

TARDIF, Maurice. LESSARD, C.; LAHAYE. Os professores face ao saber: esboço de uma problemática do saber docente. Teoria e educação. n. 4, 1991.

TEZZA, Cristóvão. Sobre a autoridade poética. In: FARACO, Carlos Alberto; TEZZA, Cristovão; CASTRO, Gilberto de. Vinte ensaios sobre Mikhail Bakhtin. Petrópolis (RJ): Vozes, 2006, p. 235-254.

Discurso poético e discurso romanesco na teoria de Bakhtin. In: FARACO, Carlos Alberto et al. Uma introdução a Bakhtin. São Paulo: Hatier, 1988, p 53-71. 
WILLIS, Roy. Mitologias. deuses, heróis e xamãs nas lendas de todo mundo. São Paulo: Publifolha, 2007.

ZEICHENER, Kenneth. Formando professores reflexivos para educação centrada no aluno: possibilidades e contradições. In: BARBOSA, Raquel Lazzari (org.). Formação de educadoresdesafios e perspectivas. São Paulo: Editora UNESP, 2003, p. 35-55. 